\title{
Effect of Sport Education Model-Based Social-Emotional Learning Program on Emotional Intelligence
}

\author{
Neslihan ARIKAN ${ }^{1}$ \\ ${ }^{1}$ Faculty of Sport Science, Gazi University, Ankara, Turkey \\ Correspondence: Neslihan ARIKAN, Abant Caddesi 10/1C D:1d, 06210 Yenimahalle, Ankara, Turkey. E-mail: \\ neslihanarikangazi@gmail.com
}

Received: October 25, 2019

Accepted: December 18, 2019

Online Published: February 27, 2020

doi:10.5539/ies.v13n4p41

URL: https://doi.org/10.5539/ies.v13n4p41

\begin{abstract}
In the study, a 16-week SEM-SEL volleyball program was prepared using the Social-Emotional Learning Model (SEL) based on the Sport Education Model (SEM). The goal achievements of SEL are processed and awareness about the goal achievements is provided to the students in the SEM-SEL volleyball program each week. In the study, pattern with experimental pre-test final-test control group was used. Experiment and control groups were formed in all three-school types. The 16-week SEM-SEL program was applied to the students in the experimental groups and the current curriculum was applied to the students in the control groups. The Schutte Emotional Intelligence Scale (SEI-S) was used as a data tool. Descriptive statistics and Two-way Covariance Analysis (ANCOVA) were used for data analysis. As a result of the descriptive statistics, it was determined that there were significant differences between the SEI-S total scores of the experiment and control groups; that there was an increase in the emotional intelligence levels of the students in the experiment group and a decrease in the students in the control group. According to ANCOVA, SEI-S final-test total scores were found to have a significant difference in favor of the experimental group and no significant difference in the school type. Consequently, the 16-week SEM-SEL volleyball program was effective in increasing the emotional intelligence levels of the students. Furthermore, it was determined that SEM and SEL were compatible with each other and that SEL had positive results in the field of physical education and sports.
\end{abstract}

Keywords: emotional intelligence, physical education, sports education model, social-emotional learning

\section{Introduction}

One of the most important processes in an individual's development is socialization. As of birth, individuals are expected to be compatible and socialized within the community. Socialization is the process in which individuals, especially children, become functional members of a particular group and gain the values, behaviors, and beliefs of other members of the group. It is very important for people to adapt to the physical and social environment they are in and to lead a healthy, happy and successful life (Baran, 2011; Driscoll \& Nagel, 2008; Gander \& Gardiner, 2007).

The emotional development is whether or not the effects or events from the inner and outer worlds of individuals are pleasing to him or not. Emotional development, which goes parallel to cognitive, language and social development, means that the child is aware of his/her emotions, knows himself/herself, knows his/her competence and inadequacies, expresses and supervises his/her emotions in inappropriate ways. In order to become an effective member of society, one needs to realize his social-emotional development according to his age (Baran, 2009; Pedük, 2011).

The dimensions of emotion (emotional), relationship building (social), and fulfillment (task-oriented) are widely used in literature to describe areas of social-emotional learning (M. Lawson \& H. Lawson, 2013; Shecktman, De Barger, Dornsife, Rosier, \& Yarnall, 2013). Social-emotional learning (SEL) is defined as the process of recognizing the feelings of oneself and others, being sensitive to their needs, expressing and managing emotions, recognizing their strengths and weaknesses, developing the skills needed to sustain life tasks such as communicating effectively and maintaining them (Elias, 2003). The emergence of social-emotional learning as a field has been influenced by ecological models of approach and cognitive development, which nurture the social, emotional and academic competence of individuals, carefully evaluate the formations involved and the interrelationships between individuals (Bronfenbrenner \& Ceci, 1994). SEL the on five interrelated competencies 
from the cognitive, behavioral and emotional fields: self-awareness, self-management, positive decision-making, relationship skills, and social awareness (Collaborative for Academic, Social, and Emotional Learning, 2014).

The struggle of the individual towards social and emotional difficulties affecting their ties with the school and their school performance is an issue that needs to be emphasized. Issues like discontent, lack of belonging, alienation, indiscipline, and leaving school often limit success in school and even lead to failure (Manz, 2007). In this regard, Adelman and Taylor (2000) argue that schools will likely fall behind their goals if they focus solely on academic teaching and school management in their efforts to help students achieve academic success.

SEL plays an important role in the functioning of these stages by helping students to use the classroom effectively in a social and emotional sense and creating environments conducive to learning by schools (Manz, 2007). Those who are successful in social-emotional learning can recognize and manage their emotions, establish healthy relationships, set positive goals, meet their personal and social needs, and make responsible ethical decisions (Elias et al., 1997; Payton et al., 2000).

SEL gives the individual many positive qualities like listening and verbal communication, compatibility, creative thinking and problem solving, self-esteem, goal setting, self-motivation, interpersonal communication skills, reconciliation, teamwork, proficiency in reading, writing and computing (Uşakl1, 2017).

SEL is quite important not just for students but for all people. Our emotional state in a learning environment affects what, how and how much we learn (Uşakl1, 2008). In such a case, emotion comes into play. Emotions are internal guides, leading the individual to communicate by responding to signals from others. The main emotions that cause stimulation in the body can be listed as anger, sadness, fear, pleasure, love, astonishment, disgust and shame. Individuals do not only rely on logic when making decisions, but they also need an emotional build-up brought on by their past experiences. Focusing of intelligence-focused researches on brain has shown that when emotional bonds break, even simple decisions cannot be made (Goleman, 1996, 1998). One of the major contributions of studies on this subject is the concept of emotional intelligence. Goleman $(1996,1998)$ explained in his examples related to the split of emotional ties that emotional intelligence is not only abstract, but also has neuropsychological and physiological dimensions. The concept of emotional intelligence originated based on a series of scientific disciplines. A model has been established in order to improve human relations in daily life in education and working life and to prevent the negativity caused by human relations (Acar, 2001).

Emotional intelligence is the ability of individuals to recognize themselves and other people's emotions, to distinguish different emotions, to understand them appropriately, to use emotional information to guide behavior, to manage or apply emotions to adapt to the current environment (Brody, 2004). Yang, Read, and Miller (2009) states that emotions are a result of internal and external particles of information that can change from time to time, occurring after interacting with a human's environment. Emotional intelligence reflects not a single feature or ability, but a combination of different reasoning abilities like sensing, understanding, and classifying emotions (Bukaliya \& Rupande, 2015).

Oatley, Keltner, and Jenkins (1996) argue that emotion has the potential to reinforce an individual's thinking, but emotional states also have the potential to interfere with learning. Sparrow and Knight (2006) view emotions as multi-component reaction tendencies that occur during a relatively short period of time. Reiff et al. (2001) consider that emotions are primarily motivated by the forces that evoke, sustain, and direct action. They stated that emotions affect a variety of behaviors, like learning, helping, bargaining, aspiring for the goodness of others, taking risks, and compatibility (Bukaliya \& Rupande, 2015).

Parker et al. (2004) with Bar-on (1997), a pioneer and one of the leading researchers in the study of emotional intelligence and Petrides, Frederickson, and Furnham (2004) argue that emotional intelligence is closely related to the academic achievements of individuals, that this non-cognitive ability is related to the effect on an individual's Life Achievement, their ability to manage their emotions.

They pointed out in a study made by Lau (2006) that students with high emotional proficiency were likely to make more effort in their academic studies. Another study by Schutte et al. (2001) found that emotional intelligence plays an important role in establishing and maintaining relationships, and Saarni (1999) found that the relevant structure of emotional competence contributes to the quality of interpersonal relationships as an important component of social development.

Emotional intelligence studies are mostly conducted in the fields of education and physiology. By noting the importance of research on how children learn, Hopfl and Linstead (1997) argue that children not only learn content, but also learn how to value their work, how to build a relationship with their peers, and how to feel for their teachers and friends. This shows that successful learning and successful performance are due to the 
development of rational and emotional competence (Seligman, 1998). It is also seen that this has a significant place in school success, as good personal relationships allow the individual to integrate socially into the school system and can effectively discuss academic issues with his or her peers (Bukaliya \& Rupande, 2015).

When schools integrate their efforts to encourage individuals to learn academically, socially and emotionally, they are at their most successful point in the fight for fulfilling their educational duties. Schools are social spaces, and learning is also a social process. Students take the learning activities in cooperation with the support of their teachers and their families (Elias et al., 1997). In this context, sports education is also facing the individual through school, that is, through education.

The conceptual foundations of sports training are derived from game training. Siedentop has suggested that the meaning of physical education is best explained by the concept of play. Siedentop (2002) said that the game could attract the participant in a strong and holistic manner. He revealed that the play could mobilize students and encourage them to be physically active for the rest of their lives.

The Sport Education Model (SEM) was first described in 1986 by Siedentop, Mand and Taggart. In 1994, Siedentop provided a more authentic approach to physical educators for the teaching of sports. Sports training is designed to help individuals better understand sport in all competitions, thanks to improvements in long-term programming in team selection, pre-season workouts, competitions, record keeping, and official refereeing (Bennett \& Hastie, 1997).

The rationale for sports training is simple and understandable. It is important to be able to teach the sports culture to the new generations and the best place to do this is the school programs. Undoubtedly, children and young people are able to learn about sports culture in many ways. But the best place to provide a wide range, educational and egalitarian sports experiences is education systems. Therefore, SEM is designed as a way to transfer sports culture, which contains the most positive characteristics of the sport, from generation to generation (Metzler, 2011). SEM was developed because of shortcomings such as teaching physical education teachers only technical skills, without teaching students how to play the game for any sport, the rules that should be applied, or the rituals that are followed in competitions on the game (Siedentop \& Tannehill, 2000). The primary goal of sports education is to educate knowledgeable, skillful and willing sportspeople (Siedentop, 1994).

Siedentop (1994), for sports education, addresses a number of specific learning goals. These include: developing sports-specific skills and physical fitness; implementing strategic games within sports and appreciating good practices; participating in the development of students at the appropriate level; sharing in the planning and management of sports experiences; providing responsible leadership; working effectively towards common goals within a group; appreciating the rituals and rules that give meaning to sports; developing the capacity to make causal decisions about sport issues, apply and develop the information related to refereeing and training, being volunteer to participate in sports. SEM programs are prepared by considering these goals.

In addition to these goals, researches on sports education point out that the model provides a number of benefits for students and teachers in physical education. Benefits for students include an enhanced personal investment in physical education, equal opportunity for girls and low-skilled students' participation, and an increase in student achievement levels. The benefits for teachers are expressed as an increase in freedom over direct teaching, a greater focus on the individual needs of students, and a renewed interest in teaching (Mohr, Townsend \& Pritchard, 2006). SEM offers an effective alternative to traditional approaches in teaching physical activity as part of a healthy lifestyle.

As a pedagogical model according to Wallhead and O'Sullivan (2005), SEM is framed in two categories: the first is the practical strategies required to implement sports education, and the educational effect of the model on student learning by its various dimensions. The second is the students' personal and social development, that is, their attitude (enthusiasm, motivation, etc.) and their values (closeness, equality, etc.) according to the consistent results. SEM is associated with improved social behavior in sport, particularly in relation to fair play. A number of studies made by Wallhead and O'sullivan (2005) and Hastie, de Ojeda, and Luquin (2011) support this proposition.

It has been reported that it will be more effective to present SEL with special teaching methods like role-playing, peer coaching, conflict resolution, and perspective-taking for evidence-based implementation (CASEL, 2014; Jones, 2004). SEM provides students with many positive features like working together towards common goals, making group decisions, having experiences of success and failure as a group, creating a group identity, and developing emotionally and socially (Metzler, 2011). In this context, it was thought that SEM would be compatible with SEL. In addition, SEL has been stated to be compatible with physical activity and sports, but little work has been done in this area (Ang, Penney, \& Swabey, 2011; Gordon, Jacobs, \& Wright, 2016; Talebzadeh \& Jarfari, 2012). 
As they are social institutions, schools bring together a large number of students during an important part of the day. Many children come to school by gaining social and emotional skills in their families, while many children come without acquiring them. Children can come to school without gaining skills like self-expression, expressing their wishes and feelings, coping with their intense emotions, anger management, listening, sharing, assistance and cooperation. Thus, unearned social and emotional skills can cause interpersonal conflicts and disputes in the school environment. If people do not gain these skills and competencies in school, they participate in their lives with the deprivation of these skills and competencies. Therefore, the related problems are moved to the business environment and all social relations. In this context, it is seen that it is important for people to develop social and emotional learning skills, behaviors of taking responsibility, and emotional intelligence levels as of young age.

In this study, the SEM-based SEL-volleyball program was planned to be implemented in physical education and sports courses and focused on the effect of the program on the emotional intelligence levels of the students.

\section{Method}

\subsection{Purpose of the Research}

The aim of this study is to examine the effect of the SEM-SEL Volleyball program on the emotional intelligence levels of students in three different school types. In this respect, the following questions were tried to be answered:

1) Is there a significant difference between the pretest and final test scores of the experimental and control groups applied to the SEM-SEL Volleyball program regarding the levels of emotional intelligence?

2) Does the SEM-SEL Volleyball program have any effect on the emotional intelligence levels of the students in the school to which it was applied?

\subsection{Research Pattern}

The study looked at the effectiveness of the SEM-SEL Volleyball program in improving the emotional intelligence levels of students studying in different types of schools. For this purpose, experimental and control groups of three different types of schools have been established for the implementation of the program. In this study, a pattern with an experimental pre-test final-test control group was used. The control group experiences the natural process (Büyüköztürk, 2019) while the experimental group receives the process (a new course material, a different teaching method or an application such as a training program), whose effect on the dependent variable will be tested.

\subsection{Work Group}

A sampling method for the purpose was used in the research (Yıldırım \& Şimşek, 2018). A total of 166 students in the 9th grade studying in Anatolian High School (experiment=29, control=28), Vocational Technical Anatolian High School (VTAS) (experiment=28, control=26) and Sports High School (experiment=27, control=28) affiliated to the Ministry of National Education (MNE) were included in the study in 2018-2019 academic year fall semester, in Ankara Province. In three different schools, classes forming experiment and control groups were chosen by random assignment method. The ages of the students range from 15 to 17 .

In order to determine whether the groups are equivalent in terms of emotional intelligence levels, the pre-test total scores from the Schutte Emotional Intelligence Scale were compared. The students' pre-test total scores from SEI-S were found to be in the range of -2 and +2 with skew and kurtosis coefficients and the normal distribution of the data was observed and the analyses were continued as follows (Field, 2009). The result of variance equality is shown in Table 1.

Table 1. Variance equality of pre-test total scores for students' emotional intelligence levels (One-way ANOVA)

\begin{tabular}{cccccccc}
\hline & Variables & $\mathrm{N}$ & $\overline{\mathrm{X}}$ & $\mathrm{Sd}$ & $\mathrm{Df}$ & $\mathrm{F}$ & $\mathrm{p}$ \\
\hline \multirow{4}{*}{ Pre-test } & Experiment & 84 & 129.60 & 13.41 & 1 & 3.742 & .167 \\
\cline { 2 - 8 } & Control & 82 & 133.81 & 14.61 & 164 & & \\
\cline { 2 - 8 } & Anatolian High School & 57 & 133.19 & 13.97 & 2 & & \\
& VTAS & 54 & 131.90 & 15.85 & 163 & .305 & .136 \\
& Sports High School & 55 & 129.90 & 131.68 & & & \\
\hline
\end{tabular}

$\mathrm{p}<.05$.

According to Table 1, there was no significant difference in the pre-test scores for the emotional intelligence levels of the students in the experimental and control groups $\left.{ }_{(\mathrm{F}(1,164)}=3.742, \mathrm{p}>.05\right)$. There was also no significant 
difference in the pre-test scores for students' emotional intelligence levels according to school types $(\mathrm{F}(2,163)$ $=.305, \mathrm{p}>.05)$. This indicates that students' emotional intelligence levels are equivalent to each other, according to the school type and groups.

\subsection{Data Collection Tool}

The Schutte Emotional Intelligence Scale was used in the research.

Schutte Emotional Intelligence Scale (SEI-S). It was developed by Schutte, Malouff, Hall, Haggerty, Cooper, Golden, and Dornheim (1998) and reorganized as Article 41 by Austin, Saklofske, Huang, and McKenney (2004). The scale is of the quintet Likert type and consists of three sub-dimensions: optimism/regulation of mood, use of emotions, and evaluation of emotions.

The scale, adapted to Turkish by Tatar, Tok, and Saltukoğlu (2011), was applied to a total of 1743 people between the ages of 17-78, 1022 women (58.6\%) and 721 men (41.4\%). For the whole Cronbach-Alpha internal coherence coefficient .82 , for its lower dimensions $.75, .39$ and .76 has been identified. For the whole of the Cronbach-Alpha, the internal coherence coefficient of the scale applied to a total of 166 students in this study .69 and for its lower dimensions $.58, .56$ and .65 has been identified.

\subsection{Data Collection Process}

The study planned as one day, 16 weeks, 16 courses and 32 hours in total in the Physical Education and Sports course in the curriculum during the fall semester of the 2018-2019 academic year, with the students studying in 9th-grade classes (experiment $=84$ ) in three different types of schools in Ankara, which are affiliated to the MNE. The contents and sample applications of the sources of Siedentop, Hastie and van der Mars (2011), CASEL (2012) and Zins, Weissberg, Wang, and Walberg (2004) were examined for the preparation of lesson plans. As a result of the review, 16 courses were prepared for volleyball, including the levels of SEL and the target behaviors of SEM. The levels of SEL were placed in the volleyball season program prepared in accordance with SEM. The goal achievements of SEL are also processed and awareness about the goal achievements is provided to the students in the SEM-SEL volleyball program each week.

The research was conducted in three different types of schools. The functioning of all three types of schools is different. Students attending Sports High School attend applied sports classes in half of the weekly course hours, and in the other half, they see academic courses. Anatolian High School is fully academic and has curriculum for preparing for the University. In VTAS, students receive vocational training mainly for their chosen branches (computers, electricity, chemistry, child development, etc.) along with academic courses).

Voluntary consent forms were distributed to students in the experimental and control groups after they were informed about the study. After the approval forms were collected, SEI-S was applied for the pre-test. The SEM-SEL Volleyball program to students in experimental groups for 16 weeks. The current curriculum has with the students in the control groups. The current teaching programs of experimental studies and control groups were conducted by physical education teachers who were in charge of the schools. Physical education teachers carrying out experimental studies were given seminars about the functioning of the program and necessary documents and materials related to the course contents were provided. After the application, SEI-S was re-applied to the students in the experimental and control groups as a final-test. Experimental applications are shown in Table 2. 
Table 2. Experimental applications of research

\begin{tabular}{|c|c|c|c|}
\hline Week & Level & Gain & Event \\
\hline 1 & Self-awareness & Respecting yourself and others, self-control & Setting rules, setting levels \\
\hline 2 & Self-awareness & $\begin{array}{l}\text { Finding logical solutions to problems, reassuring each other, } \\
\text { communicating. }\end{array}$ & Play rules, technical work \\
\hline 3 & Self-awareness & Self-control, respect for yourself and others & $\begin{array}{l}\text { Historical development of volleyball in the } \\
\text { world, technical study }\end{array}$ \\
\hline 4 & Self-management & Controlling emotions, setting goals & $\begin{array}{l}\text { Historical development of volleyball in } \\
\text { Turkey, technical study }\end{array}$ \\
\hline 5 & Self-management & $\begin{array}{l}\text { Controlling the feelings of winning and losing, taking } \\
\text { responsibility }\end{array}$ & $\begin{array}{l}\text { Nutrition and health of sportsperson, } \\
\text { technical study }\end{array}$ \\
\hline 6 & Self-management & $\begin{array}{l}\text { Controlling the feelings of winning and losing } \\
\text { self-regulation }\end{array}$ & $\begin{array}{l}\text { The benefits of regular physical activity, } \\
\text { technical study }\end{array}$ \\
\hline 7 & $\begin{array}{l}\text { Positive } \\
\text { decision-making }\end{array}$ & $\begin{array}{l}\text { Strategy development, showing leadership, communicating, } \\
\text { motivation. }\end{array}$ & $\begin{array}{l}\text { Volleyball organizations in the world, } \\
\text { technical work }\end{array}$ \\
\hline 8 & $\begin{array}{l}\text { Positive } \\
\text { decision-making }\end{array}$ & $\begin{array}{l}\text { Making effort, participation, problem-solving, decision } \\
\text { making, evaluation of the result }\end{array}$ & $\begin{array}{l}\text { Volleyball organizations in Turkey, } \\
\text { technical study }\end{array}$ \\
\hline 9 & $\begin{array}{l}\text { Positive } \\
\text { decision-making }\end{array}$ & Goal setting, self-development, decision-making & $\begin{array}{l}\text { Safety rules to be considered in sports } \\
\text { fields, technical study }\end{array}$ \\
\hline 10 & Relationship skills & $\begin{array}{l}\text { Self-responsibility, motivation, focusing, a relationship } \\
\text { building, maintaining relationship }\end{array}$ & Technical work, adopting tasks \\
\hline 11 & Relationship skills & Focusing, cooperating, active listening, negotiating conflict & Technical work, adopting tasks \\
\hline 12 & Relationship skills & Setting goals, establishing relationships, self-responsibility & Technical work, adopting tasks \\
\hline 13 & Social awareness & $\begin{array}{l}\text { Social awareness, creativity, self-expression, and } \\
\text { collaboration }\end{array}$ & Technical work, adopting tasks \\
\hline 14 & Social awareness & $\begin{array}{l}\text { Social awareness, creativity, self-expression, and } \\
\text { collaboration }\end{array}$ & Technical work, adopting tasks \\
\hline 15 & Social awareness & Strategy development, showing leadership, social awareness & Post-season competitions \\
\hline 16 & Social awareness & $\begin{array}{l}\text { Creative thinking, cooperation, self-expression, leadership, } \\
\text { empathy }\end{array}$ & Post-season competitions \\
\hline
\end{tabular}

The SEM has six important features: seasons, team membership, official competitions, result event, record keeping and festival (Siedentop, 1994). According to these features, volleyball courses were followed in a seasonal format comprising 16 weeks, students were divided into equivalent groups and team members were formed and continued their membership in the same team throughout the season. Volleyball-oriented acting and non-acting (team manager, coach, referee, conditioning, health officer, statistician, press member, organization officer, materialist, etc.) tasks were given to the students and pieces of training about tasks were given. Official competitions were held as joined with volleyball season, consequential events were held with awards and celebrations, records were kept about the activities and the season was continued as a peak event in the festival mood (taking team photos, finding names for teams, selecting gentlemen and sportsmen players, celebrating, attracting attention to team success and individual achievements and announcing them regularly, etc.).

Prior to the research, approval was taken from Gazi University, Commission of Scientific Research and Publication Ethics and all students. The students were informed about the content of the research and the rights they have. The students were informed that participation in the study would certainly not have any effect on the course grades and in participation, volunteering was based on.

\subsection{Data Analysis}

In the analysis of the data, standard deviation and mean analysis for descriptive statistics of pre-test and final-test scores obtained from SEI-S; One-way ANOVA analysis for determining variance equality of groups; two-way Covariance Analysis (Two-way ANCOVA) was used to check the pre-test scores of the groups and determine if there was a differentiation between the final-test scores. The SPSS 20.0 package program was used.

\section{Findings}

The students' pre-test and final-test total scores from SEI-S were found to be in the range of -2 and +2 with skew and kurtosis coefficients and the normal distribution of the data was observed data, the analyses were continued as follows (Field, 2009). The Skewness and Kurtosis values are given in Table 3. 
Table 3. The Skewness and Kurtosis Values of the SEI-S

\begin{tabular}{lcccccc}
\hline & & $\mathrm{N}$ & \multicolumn{2}{c}{ Skewness } & \multicolumn{2}{c}{ Kurtosis } \\
\hline \multirow{3}{*}{ Pretest } & Variables & Statistic & Statistic & Std.Error & Statistic & Std.Error \\
\cline { 2 - 7 } & Experiement & 84 & 1.185 & .263 & 1.366 & .520 \\
& Control & 82 & .605 & .266 & .237 & .526 \\
\cline { 2 - 7 } Posttest & Experiement & 84 & -.447 & .263 & .908 & .520 \\
& Control & 82 & -.347 & .266 & -.378 & .526 \\
\hline \multirow{3}{*}{ Pretest } & Anatolian High School & 57 & .542 & .316 & -.424 & .623 \\
& VTAS & 54 & .984 & .325 & .684 & .639 \\
& Sports High School & 55 & 1.040 & .322 & 1.831 & .634 \\
\cline { 2 - 7 } Posttest & Anatolian High School & 57 & -.479 & .316 & .182 & .623 \\
& VTAS & 54 & -.638 & .325 & 1.767 & .639 \\
& Sports High School & 55 & -.148 & .322 & -.566 & .634 \\
\hline
\end{tabular}

The mean and standard deviation values of the pretest and posttest scores as the types of schools of the students obtained from SEI-S are given in Table 4.

Table 4. Mean $(\overline{\mathrm{X}})$ and Standard Deviation (Sd) of SEI-S

\begin{tabular}{|c|c|c|c|c|c|c|c|}
\hline \multirow{2}{*}{ Sub-scales } & \multirow{2}{*}{ Type of school } & \multirow{2}{*}{ Group } & \multirow{2}{*}{$N$} & \multicolumn{2}{|c|}{ Pre-test } & \multicolumn{2}{|c|}{ Post-test } \\
\hline & & & & $\overline{\mathrm{X}}$ & $\mathrm{Sd}$ & $\overline{\mathrm{X}}$ & $\mathrm{Sd}$ \\
\hline \multirow{8}{*}{ Optimism/Mood Regulation } & \multirow{2}{*}{ Anatolian High School } & Experiment & 29 & 44.10 & 6.64 & 38.37 & 3.82 \\
\hline & & Control & 28 & 43.89 & 5.11 & 41.78 & 5.06 \\
\hline & \multirow{2}{*}{ VTAS } & Experiment & 28 & 41.39 & 6.17 & 41.03 & 2.57 \\
\hline & & Control & 26 & 40.73 & 8.87 & 43.26 & 3.73 \\
\hline & \multirow{2}{*}{ Sports High School } & Experiment & 27 & 42.88 & 7.85 & 41.92 & 6.53 \\
\hline & & Control & 28 & 38.03 & 3.19 & 37.39 & 2.55 \\
\hline & \multirow{2}{*}{ Total } & Experiment & 84 & 42.80 & 6.91 & 40.40 & 4.77 \\
\hline & & Control & 82 & 40.89 & 6.50 & 40.75 & 6.23 \\
\hline \multirow{8}{*}{ Utilizations of Emotions } & \multirow{2}{*}{ Anatolian High School } & Experiment & 29 & 15.00 & 3.11 & 19.20 & 2.75 \\
\hline & & Control & 28 & 19.78 & 3.21 & 17.92 & 3.39 \\
\hline & \multirow{2}{*}{ VTAS } & Experiment & 28 & 18.75 & 3.25 & 18.71 & 2.57 \\
\hline & & Control & 26 & 18.03 & 4.17 & 17.11 & 3.47 \\
\hline & \multirow{2}{*}{ Sports High School } & Experiment & 27 & 17.66 & 4.21 & 17.25 & 3.41 \\
\hline & & Control & 28 & 18.53 & 3.08 & 18.96 & 2.63 \\
\hline & \multirow{2}{*}{ Total } & Experiment & 84 & 17.10 & 3.85 & 18.41 & 3.01 \\
\hline & & Control & 82 & 18.80 & 3.53 & 18.02 & 3.23 \\
\hline \multirow{8}{*}{ Appraisal of Emotions } & \multirow{2}{*}{ Anatolian High School } & Experiment & 29 & 25.75 & 5.46 & 32.17 & 3.10 \\
\hline & & Control & 28 & 33.89 & 5.50 & 28.03 & 5.29 \\
\hline & \multirow{2}{*}{ VTAS } & Experiment & 28 & 29.28 & 4.22 & 30.92 & 3.07 \\
\hline & & Control & 26 & 31.03 & 5.72 & 26.15 & 5.26 \\
\hline & \multirow{2}{*}{ Sports High School } & Experiment & 27 & 30.81 & 5.37 & 29.85 & 7.77 \\
\hline & & Control & 28 & 30.57 & 3.28 & 30.25 & 4.76 \\
\hline & \multirow{2}{*}{ Total } & Experiment & 84 & 28.55 & 5.43 & 31.01 & 5.11 \\
\hline & & Control & 82 & 31.85 & 5.10 & 28.19 & 5.31 \\
\hline \multirow{8}{*}{ Total } & \multirow{2}{*}{ Anatolian High School } & Experiment & 29 & 123.65 & 6.70 & 129.72 & 7.44 \\
\hline & & Control & 28 & 143.07 & 12.62 & 130.92 & 8.81 \\
\hline & \multirow{2}{*}{ VTAS } & Experiment & 28 & 131.46 & 15.42 & 133.71 & 6.42 \\
\hline & & Control & 26 & 132.38 & 16.60 & 130.38 & 9.49 \\
\hline & \multirow{2}{*}{ Sports High School } & Experiment & 27 & 134.07 & 14.64 & 132.11 & 10.13 \\
\hline & & Control & 28 & 125.89 & 8.39 & 124.32 & 9.05 \\
\hline & \multirow{2}{*}{ Total } & Experiment & 84 & 129.60 & 13.41 & 131.82 & 8.18 \\
\hline & & Control & 82 & 133.81 & 14.61 & 128.50 & 9.50 \\
\hline
\end{tabular}


According to the SEI-S final-test total scores, it is seen that there was an increase in the emotional intelligence levels of the students in the experimental group and a decrease in the students in the control group. When the SEI-S is examined according to the lower dimensions, it is observed that the students in the experimental groups had a decrease in the optimism/ mood regulation scores, an increase in the scores of the use of emotions and evaluation of emotions, and a decrease in the control groups in all three lower dimensions.

Furthermore, when the SEI-S total scores of the experimental groups are examined according to the type of school, it is observed that Anatolian High School score averages have increased from $X=123.65$ to $X=129.72$, VTAS's average has increased from $X=131.46$ to $X=133.71$, and Sports High School has decreased from $X=134.07$ to $\mathrm{X}=132.11$. According to the results, the most increase was in the emotional intelligence scores of the students who studied in Anatolian High Schools. The decline in Sports High School is significant.

Two-way ANCOVA analysis was conducted to determine whether there was a significant difference between the final-test scores when the students' pre-test scores were checked by groups and school types. The results of the analysis are given in Table 5.

Table 5. Two-way ANCOVA results for SEI-S

\begin{tabular}{|c|c|c|c|c|c|c|}
\hline Source & Type III Sum of squares & Df & Mean square & $F$ & $p$ & $\mathrm{n}^{2}$ \\
\hline Covariate (pretest) & 71.41 & 1 & 71.41 & .959 & .329 & .006 \\
\hline Type of school & 377.91 & 2 & 188.95 & 2.539 & .082 & .031 \\
\hline Group & 499.49 & 1 & 499.49 & 6.711 & $.010 *$ & .040 \\
\hline Type of school* group & 333.61 & 2 & 166.80 & 2.241 & .110 & .027 \\
\hline Error & 11834.88 & 159 & 74.43 & & & \\
\hline Total & 2826546.00 & 166 & & & & \\
\hline Corrected total & 13340.57 & 165 & & & & \\
\hline
\end{tabular}

Note. $p<.05^{*}$, Dependent variable: posttest.

According to Table 5, when SEI-S pre-test total scores are checked and final test total scores are examined; it was found out that there was no significant difference between the scores of the groups in terms of emotional intelligence levels according to school type $[\mathrm{F}(2 ; 159)=2.539, \mathrm{p}>.05]$. According to the Bonferroni test results, a significant difference was found between the final test scores between the experimental group $(X=131.92)$ and the control group $(\mathrm{X}=128.43)$ in favor of the experimental group. Although there was an increase in the emotional intelligence levels of the students in the experimental group, this increase was not statistically significant in terms of school type. According to Kinnear and Gray's (1999) classification, the effect factor on emotional intelligence level is observed to be quite high in effect in experimental groups $\left(\mathrm{n}^{2}=.040\right)$. Additionally, participation in the SEM-SEL volleyball program was found to have no significant effect on emotional intelligence scores of school types $[\mathrm{F}(2,159)=2.241, \mathrm{p}>.05]$. This indicates that the emotional intelligence levels of the students who participate in and do not participate in the SEM-SEL volleyball program do not change depending on the type of school they are studying.

\section{Discussion and Conclusion}

In this study, the SEM-SEL volleyball program was applied for 16 weeks to students studying in three different schools and the effect of the program on emotional intelligence according to school types was examined. Research results have shown that the SEM-SEL volleyball program is effective in the development of students' emotional intelligence levels. Additionally, the study shows that SEM and SEL are compatible with each other. This result is proof that SEM-based sports education facilitates SEL in students. Another result of the research is that SEL has positive results in the field of physical education and sports. It provides positive evidence for schools wishing to implement SEL in physical education and sports classes.

According to the SEI-S final-test total scores, it is determined that there was an increase in the emotional intelligence levels of the students in the experimental group and a decrease in the students in the control group. Therefore, it can be stated that the SEM-SEL Volleyball program has an effect on the development of emotional intelligence levels of students. When the SEI-S is examined according to the lower dimensions, it is observed that there is a decrease in the behavior of experimental and control groups such as "evaluating their experiences, finding activities where they can be happy, being able to overcome problems more easily, complimenting people, being optimistic, producing new ideas in emotion changes sports. Environments should be created in schools that allow students to experience different emotions and moods and make the right decisions, demonstrate the solutions 
and possible consequences of their problems, and understand how they should behave. However, when the mood changes, there is an increase in experimental groups and a decrease in control groups in behaviors like seeing new possibilities, affecting the quality of life by emotions, contribution of emotions in generating ideas and solving problems. Therefore, it can be stated that the students control their emotions at the end of the program, and they can also benefit from their feelings at the decision stage. In addition, at the end of the program, there was an increase in the behaviors of students in experimental groups like understanding non-verbal messages of people, distinguishing that they were serious or joking, communicating with people, more easily, establishing close friendships, and decrease in students in control groups. Therefore, it can be stated that the SEM-SEL Volleyball program improves students' showing empathy, understanding the feelings of others and communicating comfortably with others. It is important to investigate the reasons why emotional intelligence levels in control groups fall.

In addition, it was determined that the increase in emotional intelligence scores was the highest in Anatolian High School and the decrease in Sports High School. In Anatolian High School, a curriculum focused solely on academic achievement is being prepared. The SEM-SEL volleyball program, which aims to gain empathy, to understand the feelings of others, to experience the feelings of winning and losing, may have attracted the interest of the students. This result shows that such programs, which are also implemented in school types that target only academic achievement, may improve students' social-emotional learning skills. Students in these schools also need to develop their cognitive, social, affective and physical characteristics through various activities.

At the end of the program, the decrease in emotional intelligence levels of the students in Sports High School is significant, and the reason for the decline must be investigated. In this type of school, sports training is provided, which includes different branches of techniques-tactics. In general, learning by instruction, practice, peer-to-peer study and participation methods are used in courses; methods like guided invention, problem-solving, and individual evaluation are almost never used. Teachers usually practice their classes as if they are training at a sports club. Therefore, students are not given opportunities like thinking, researching, analyzing, exploring. Physical Education Teachers in charge of this program may be focused on skills learning rather than activities aimed at goal attainment in lessons. In the model-based application study, it is important every researcher has demonstrated good compliance with the model (Kirk, 2013). Regarding the subject of the degree of loyalty that arises in practical applications, Curtner-Smith, Hastie, and Kinchin (2008) found that teacher candidates have varying degrees of commitment to sports education. According to Dyson and Casey (2012), it is common for teachers to change their model-based teaching according to their preferences. However, Gordon and Doyle (2015) are careful not to automatically reject variations in the model in some cases, stating that there may be flexibility in model applications, but flexibility should not proceed.

In addition, Sports High Schools train candidates for future Physical Education Teacher. It is a perilous consequence that there is a fall in these students' level of emotional intelligence. Because these students will become physical education teachers in future sports is important for teachers to understand their students' feelings, what they want to tell, their secret messages, and the way they communicate. In this context, the teaching methods of physical education and sports courses given in Sports High Schools, or more precisely in all schools, need to change urgently. Students should be presented with an educational model in which they will gain activities like raising awareness about their emotions, empathizing, taking responsibility, helping others, controlling their emotions, etc.

According to the results of this study, it was found that there was a significant difference in the emotional intelligence scores of the students in favor of the experimental group; however, there was no significant difference according to school type. It was also found that the joint effect of the experimental group and school type on emotional intelligence scores was not significant. Therefore, it can be stated that the school type is not effective in changing the emotional intelligence levels of the students participating in the SEM-SEL volleyball program.

In this current study, only the SEM-SEL volleyball program was applied. Different parameters were also examined during the experimental study process, but the study focused solely on the effect of emotional intelligence levels in three different school types of the program. Future studies can be done in different model combinations, different age groups, and different sport branches by making analysis in different parameters (self-efficacy, attitude, individual-social responsibility etc.).

\section{Recommendations}

In addition to the ability of emotions to facilitate students' learning and their absolute success in school, they can make their success more difficult by creating an opposite situation. While social and emotional factors have such an important place on the student, schools need to rearrange the educational process in order to benefit the students. 
In order to improve the emotional intelligence level of the individual, all of the educational programs of family education, preschool education, primary and secondary education and adult education should be reorganized with this understanding. The importance of emotional intelligence in the development of students' personalities should not be ignored and all levels of education, and especially in the preschool term, should be carefully included in the programs. In schools, students should be provided with environments where they can interact with nature, society, environment, peers. In this context, parameters to contribute to sports education programs should be developed in cooperation and hand in hand with management, parent-teacher association, and parents.

Administrators and teachers in schools should be composed of individuals who adopt emotional intelligence values and attitudes. As well as providing emotional and social skills in teaching programs in schools, programs that develop these activities outside of the course should also be prepared. The development of appropriate methods, environments, strategies and techniques to be used in order to use an accurate and effective way to reflect emotional intelligence competencies on educational programs and increase of the scientific studies that will ensure the creation of new instructional designs are necessary. Models like SEM can be used to enable students to develop emotional areas, especially in sports.

\section{References}

Acar, F. T. (2001). Relationship between Emotional Intelligence Capabilities and Task-Based Leadership Behaviors: A Field Study on Bank Branch Managers (Ph.D. thesis, Istanbul University, Institute of Social Sciences, Istanbul).

Adelman, H. S., \& Taylor, L. (2000). Moving Prevention From The Fringes İnto The Fabric Of School İmprovement. Journal of Education and Psychological Consultation, 11(1), 7-36. https://doi.org/10.1207/s1532768xjepc1101_3

Ang, S. C., Penney, D., \& Swabey, K. (2011). Pursuing Social And Emotional Learning Outcomes Through Sport Education. In P. Hastie (Ed.), Sports Education: International perspectives (pp. 116-132). NY: Routledge.

Austin, E. J., Saklofske, D. H., Huang, S. H., \& McKenney, D. (2004). Measurement of trait emotional intelligence: Testing and cross-validating a modified version of Schutte et al.'s (1998) measure. Personality and individual differences, 36(3), 555-562. https://doi.org/10.1016/s0191-8869(03)00114-4

Baran, G. (2009). Emotional Development. Early Childhood Development and Education (pp. 101-117). Istanbul: Kriter Publishing.

Baran, G. (2011). Social Development. Child Development (pp. 193-222). Istanbul: Ya-Pa Publishing.

Bar-On, R. (1997). The Emotional Quotient Inventory (EQ-I): A Test Of Emotional Intelligence. Toronto: Multi-Health Systems.

Bennett, G., \& Hastie, P. (1997). A Sport Education Curriculum Model For A Collegiate Physical Activity Course. Journal of Teaching in Physical Education, Recreation and Dance, 68(1), 39. https://doi.org/10.1080/07303084.1997.10604876

Brody, N. (2004). What Cognitive Intelligence is and What Emotional Intelligance Is Not? Psychological Inquiry. 15(3), 234-238. https://doi.org/10.7551/mitpress/7404.003.0008

Bronfenbrenner, U., \& Ceci, S. J. (1994). Nature-Nurture Reconceptualized İn Developmental Perspective: A Biological Model. Psychological Review, 101(4), 568-586. https://doi.org/10.1037/0033-295x.101.4.568

Bukaliya, R., \& Rupande, G. (2013). Mitigating the Effects of Dwindling Resource Base in Open and Distance Learning through Community Service Programmes. Greener Journal of Educational Research, 3(5), 206-216. https://doi.org/10.15580/gjer.2013.5.062713692

Büyüköztürk, Ş. (2019). Manual of Data Analysis For Social Sciences. Statistics, Research Design, Spss Applications and Review (25th ed.). Pegem Academy.

CASEL. (2012). 2013 CASEL Guide: Effective Social and Emotional Learning Programs. Preschool and Elementary School Edition. Chicago, IL: CASEL.

CASEL. (2014). What Is Social And Emotional Learning. Retrieved from https://casel.squarespace.com/social-and-emotional-learning

Curtner-Smith, M. D., Hastie, P. A., \& Kinchin, G. D. (2008). Influence Of Occupational Socialization On Beginning Teachers' İnterpretation And Delivery Of Sports Education. Sport. Education and Society, 13(1), 97-117. https://doi.org/10.1080/13573320701780779 
Driscoll, A., \& Nagel, N. G. (2008). Early Childhood Education, Birth-Eight (4th ed.). USA: Pearson Education.

Dyson, B., \& Casey, A. (2012). Cooperative learning in physical education: A research-based approach. Routledge. https://doi.org/10.4324/9780203132982

Elias, M. J. (2003). Academic and Social-Emotional Learning. International Academy of Education (IAE) Educational Practices Series-11.

Elias, M. J., Zins, J. E., Weissberg, R. P., Frey, K. S., Greenberg, M. T., Haynes, N. M., ... Shriver, T. P. (1997). Promoting social and emotional learning: Guidelines for educators. Alexandria, VA: Association for Supervision and Curriculum Development.

Field, A. (2009). Discovering statistics using SPSS. Sage publications.

Gander, M. J., \& Gardiner, H. W. (2007). Child and Adolescent Development (6th ed., Trans: A. Dönmez, H. N. Çelen, \& B. Onur). Ankara: Imge Publishing.

Goleman, D. (1996). Emotional Intelligence: Why is it more important than IQ. Trans: Banu Seçkin Yüksel, Varlık Publishing.

Goleman, D. (1998). Emotional Intelligence at Work. Trans: Banu Seçkin Yüksel, Varlık Publishing. https://doi.org/10.1002/lt1.40619981008

Gordon, B., \& Doyle, S. (2015). Teaching Personal and Social Responsibility and Transfer of Learning: Opportunities and Challenges for Teachers and Coaches. Journal of Teaching in Physical Education, 34, 152-161. http://dx.doi.org/10.1123/jtpe.2013-0184

Gordon, B., Jacobs, J., \& Wright, P. M. (2016). Social And Emotional Learning Through A Teaching Personal And Social Responsibility Based After-School Program For Disengaged Middle-School Boys. Journal of Teaching in Physical Education, 35(4), 358-369. https://doi.org/10.1123/jtpe.2016-0106

Hastie, P. A., de Ojeda, D. M., \& Luquin, A. C. (2011). A Review Of Research On Sports Education: 2004 To The Present. Physical Education and Sport Pedagogy, 16(2), 103-132. https://doi.org/10.1080/17408989.2010.535202

Hopfl, H., \& Linstead, S. A. (1997). Introduction: Learning to Feel and Feeling to Learn: Emotion and Learning in Organizations. Management Learning, 28(1), 5-12. https://doi.org/10.1177/1350507697281001

Jones, T. (2004). Conflict resolution education: The field, the findings, and the future. Conflict Resolution Quarterly, 22(1-2), 973-986. https://doi.org/10.1002/crq.100

Kinnear, R., \& Grey, C. (1999). SPSS for Windows Made Simple. New York, NY: Psychology Press, Hove.

Kirk, D. (2013). Educational value and models-based practice in physical education. Educational Philosophy and Theory, 45(9), 973-986. https://doi.org/10.1080/00131857.2013.785352

Lau, P. S. Y. (2006). Emotional Competence As A Positive Youth Development Construct Conceptual Bases And İmplications For Curriculum Development. International Journal of Adolescent Medicine and Health, 18(3), 355-362. https://doi.org/10.1515/ijamh.2006.18.3.355

Lawson, M. A., \& Lawson, H. A. (2013). New conceptual frameworks for student engagement research, policy, and practice. Review of Educational Research, 83(3), 432-479. https://doi.org/10.3102/0034654313480891

Manz, P. H. (2007). Cultivating fertile grounds: Enhancing and extending the scientific base of social and emotional learning: A commentary on "The Scientific Base Linking Social and Emotional Learning to School Success," a chapter by Joseph E. Zins, Michelle R. Bloodworth, Roger P. Weissberg, and Herbert J. Walberg. Journal of Educational and Psychological Consultation, 17(2-3), 211-218. https://doi.org/10.1080/10474410701346642

Metzler, M. W. (2011). Instructional Models for Physical Education (3rd ed.). Scottsdale, AZ: Holcomb Hathaway.

Mohr, D. J., Townsend, J. S., \& Pritchard, T. (2006). Rethinking Middle School Physical Education: Combining Lifetime Leisure Activities and Sports Education to Encourage Physical Activity. Physical Educator, 63(1), 18-29. https://doi.org/10.1080/02701367.2017.1321100

Oatley, K., Keltner, D., \& Jenkins, J. M. (1996). Understanding Emotions. Cambridge, MA: Blackwell.

Parker, J. D. A., Creque Sr., R. E., Barnhart, D. L., Irons Harris, J., Majeski, S. A., Wood, L. M., ... Hogan, M. J. (2004). Academic Achievement İn High School: Does Emotional İntelligence Matter? Personality and 
Individual Differences, 37, 1312-1330. https://doi.org/10.1016/j.paid.2004.01.002

Payton, J. W., Wardlaw, D. M., Graczyk, P. A., Bloodworth, M. R., Tompsett, C. J., \& Weissberg, R. P. (2000). Social And Emotional Learning: A Framework For Promoting Mental Health And Reducing Risk Behavior in Children And Youth. Journal of School Health, 70(5), 179-185. https://doi.org/10.1111/j.1746-1561.2000.tb06468.x

Pedük, S.. (2011). Emotional Development. Child Development (Ed: N. Aral and G. Baran, pp. 223-258). Istanbul: Ya-Pa Publishing.

Petrides, K. V., Frederickson, N., \& Furnham, A. (2004). The Role of Trait Emotional İntelligence in Academic Performance and Deviant Behaviour at School. Personality and Individual Differences, 36, 277-293. https://doi.org/10.1016/s0191-8869(03)00084-9

Reiff, H. B., Bramel, M. H., Hatzes, N. M., \& Gibbon, T. (2001). The Relation of LD and Gender with Emotional Intelligence in College Students. Journal of Learning Disabilities, 34(1), 66-78. https://doi.org/10.1177/002221940103400106

Saarni, C. (1999). The development of emotional competence. New York: Guilford Press.

Schutte, N. S., Malouff, J. M., Bobik, C., Coston, T. D., Greeson, C., Jedlicka, C., ... Wendorf, G. (2001). Emotional Intelligence and Interpersonal Relations. The Journal of Social Psychology, 141(4), 523-536. https://doi.org/10.1080/00224540109600569

Seligman, M. (1998). Learned Optimism, Packet Books, NY.

Shecktman, N., DeBarger, A. H., Dornsife, C., Rosier, S., \& Yarnall, L. (2013). Promoting Grit, Tenacity, and Perseverance: Critical Factors for Success in the 21st Century.

Siedentop, D. (1994). Sports Education: Quality PE Through Positive Sport Experiences. Human Kinetics, Champaign, IL.

Siedentop, D. (2002). Sport Education: A Retrospective. Journal of Teaching in Physical Education, 21(4), 409-418. https://doi.org/10.1123/jtpe.21.4.409

Siedentop, D., \& Tannehill, D. (2000). Developing Teaching Skills in Physical Education (4th ed.). United States of America: Mayfield.

Siedentop, D., Hastie, P., \& Van der Mars, H. (2011). Complete guide to Sport Education (2nd ed.). Champaign, IL: Human Kinetics.

Sparrow, T., \& Knight, A. (2006). Applied EI: The Importance of Attitudes in Developing Emotional Intelligence. Publisher: Jossey-Bass.

Talebzadeh, F., \& Jarfari, P. (2012). How sport and art can be effective in the fields of social, cognitive and emotional learning. Procedia-Social and behavioral Sciences, 47, 891-903. https://doi.org/10.1016/j.sbspro.2012.06.871

Tatar, A., Tok, S., \& Saltukoğlu, G. (2011). The Adaptation of the Revised Schutte Emotional Intelligence Scale into Turkish and Investigation of Psychometric Properties. Bulletin of Clinical Psychopharmacology, 21(4), 325-338. https://doi.org/10.5455/bcp.20110624015920

Uşakl1, H. (2008). Motive and group dynamics (Ed. Z. Cafoğlu ve M. Aksüt). Ankara: Grafiker Publishing.

Uşakl1, H. (2017). What is Social Social-Emotional? Why is it important? Five Emotional Areas in Human Relations. Sinop University Journal of Social Sciences, 1(2). Retrieved from https://dergipark.org.tr/tr/pub/sinopusd/issue/32782/314566

Wallhead, T., \& O'Sullivan, M. (2005). Sport education: Physical education for the new millennium? Physical Education and Sport Pedagogy, 10, 181-210. https://doi.org/10.1080/17408980500105098

Yang, Y., Read, S. J., \& Miller L. C. (2009). The Concept of Situations. Social and Personality Psychology Compass 3/6. https://doi.org/10.1111/j.1751-9004.2009.00236.x

Yıldırım, A., \& Şimşek, H. (2018). Qualitative Research Methods. Ankara: Seckin Publishing.

Zins, J. E., Weissberg, R., Wang, M. C., \& Walberg, H. J. (2004). Building academic success on social and emotional learning: What does the research say? New York: Columbia University Teachers College Press. 


\section{Copyrights}

Copyright for this article is retained by the author(s), with first publication rights granted to the journal.

This is an open-access article distributed under the terms and conditions of the Creative Commons Attribution license (http://creativecommons.org/licenses/by/4.0/). 